\title{
PENGARUH PEMBERIAN JUS BUAH NAGA MERAH (Hylocereus polyrhezeus) DAN AKTIFITAS FISIK TERHADAP KADAR KOLESTEROL TOTAL DAN KADAR MDA (Malondialdehide)
}

\author{
Syarifah Zahra. ${ }^{1)}$,Suroto, M.Pd. ${ }^{2)}$,Ali Rosidi. ${ }^{3)}$ \\ PJKR FKIP UNWAHAS \\ szahrapjkr@gmail.com
}

\begin{abstract}
ABSTRAK
Seringnya mengonsumsi makanan yang mengandung tinggi lemak dan kolesterol memicu tingginya kadar kolesterol dalam darah yang disebut Hiperkolesterolemia yaitu suatu keadaan patologis yang disebabkan oleh kelainan metabolisme kolesterol yang kadarnya melebihi batas normal. Penelitian ini dilaksanakan dengan tujuan untuk membuktikan pengaruh pemberian jus buah naga merah dan aktivitas fisik terhadap perubahan berat badan dan menurunkan kadar kolesterol total, kadar MDA tikus Wistar hiperkoesterolemik. Penelitian menggunakan rancangan eksperimental faktorial (Factorial Experiment Design) dua faktor yaitu pemberian jus buah naga merah dan olahraga renang pada 30 ekor tikus putih dengan randomized pre test -post test only control group design, menggunakan 5 kelompok : X1 (kelompok kontrol pakan standar), X2 (kelompok pakan standar+pakan tinggi lemak), X3 (kelompok pakan standar+pakan tinggi lemak+jus buah naga merah), X4 (kelompok pakan standar+pakan tinggi lemak+aktivitas fisik) dan X5 (kelompok pakan standar+pakan tinggi lemak+aktivitas fisik+jus buah naga merah), masing-masing kelompok terdiri atas 6 ekor tikus. Variabel yang diamati adalah berat badan tikus, kadar kolesterol total dan kadar MDA pada pre dan post-test. Analisis data menggunakan paired t-test, uji Shapiro Wilk, uji Kruskal Wallis, uji Mann Whitney dan one-way Anova.Hasil pengujian menunjukkan : Rata-rata berat badan tikus sebesar 126,553 $\pm 32,954 \mathrm{~g}$. Rata-rata kadar kolesterol total sebesar 59,228 mg/dl. Rata-rata kadar MDA sebesar 1,952 $\pm 0,605 \mathrm{pmol} / \mathrm{dl}$. Kelompok yang diberi Pakan Tinggi Lemak (X2X5) rerata pertambahan berat badannya lebih tinggi daripada kelompok kontrol (X1) yang diberi pakan standar. Kelompok yang diberi pakan tinggi lemak (kelompok X2-X5) rata-rata kadar kolesterol totalnya lebih tinggi daripada kelompok yang diberi pakan standar (X1). Tidak terdapat perbedaan pengaruh antar kelompok perlakuan terhadap selisih kadar kolesterol total. Terjadi penurunan kadar MDA pada semua kelompok penelitian, dimana rata-rata penurunannya berkisar $31,975 \%$. Simpulan yg didapat pemberian jus buah naga merah dan aktivitas fisik tidak berpengaruh pada kadar kolesterol total, namun berpengaruh pada kadar MDA darah tikus hiperkolesterolemik.
\end{abstract}




\begin{abstract}
Frequent consumption of foods high in fat and cholesterol triggers high cholesterol levels in the blood and accounts for about one-third of all cardiovascular diseases in the blood. It called Hypercholesterolemia is a pathological condition caused by abnormalities of cholesterol metabolism that levels exceed the normal limit. This study aims to prove the effect of red dragon fruit juice and physical activity on body weight change and lower total cholesterol level, MDA level of Wistar hypercholesterolemic rat. This research is a type of experimental design factorial (Factorial Experiment Design) two factors namely the provision of red dragon fruit juice and sports pool on 30 white rats with randomized pre-test-only test control group design, using 5 groups : K1 (standard feed control group), K2 (standard feed group + high-fat feed), K3 (standard feed group + high-fat feed + red dragon fruit juice), K4 (standard feed group + high fat feed + physical activity) and K5 (standard feed group + high fat diet + physical activity + red dragon fruit juice), each group consisted of 6 rats. The variables observed were rat body weight, total cholesterol level and MDA levels in pre and post-test. Data analysis using paired t-test, Shapiro Wilk test, Kruskal Wallis test, Mann Whitney test and one-way Anova.

Result: The mean body weight of rats was $126.553 \pm 32.954 \mathrm{~g}$. The average total cholesterol level is $59,228 \mathrm{mg} / \mathrm{dl}$. The average MDA level of 1,952 \pm 0.605 $\mathrm{pmol} / \mathrm{dl}$. All of the high-fat-diet groups (X2-X5) on average gained more weight than the standard-diet control group (X1). Significant weight gain occurred in all treatment groups between pre-test and post-test. Groups high-fat diet (group X2X5) average total cholesterol levels were higher than the standard diet group (X1). There was no difference of influence between treatment groups on the difference of total cholesterol level. There was a decrease in MDA levels in all study groups, where the average decrease ranged from $31.975 \%$.Provision of red dragon fruit juice and physical activity has no effect on total cholesterol levels, but has an effect on blood MDA levels of hypercholesterolemic mice rat.
\end{abstract}


Pengaruh Pemberian Jus Buah Naga Merah (Hylocereus Polyrhezeus) Dan Aktifitas Fisik

Terhadap Kadar Kolesterol Total dan Kadar MDA (Malondialdehide)

Oleh : Syarifah Zahra. ${ }^{1}$ Suroto. ${ }^{2}$ Ali Rosidi ${ }^{3)}$

\section{A. PENDAHULUAN}

Perkembangan zaman yang modern, pada negara maju maupun di negara berkembang merubah kebiasaan pola hidup. Salah satunya kebiasaan pola makan, seperti makanan siap saji yang cenderung mengandung tinggi lemak dan kolesterol. Mengonsumsi makanan yang mengandung tinggi lemak dan kolesterol memicu tingginya kadar kolesterol dalam darah dan menjadi penyebab sekitar sepertiga dari semua penyakit kardiovaskuler dalam darah. ${ }^{1}$

Tingginya kadar kolesterol dalam darah yang disebut hiperkolestrolemia adalah suatu keadaan patologis yang diakibatkan oleh kelainan metabolisme kolesterol dalam darah yang kadarnya melebihi batas normal. ${ }^{2}$ Sekitar separuh kolesterol tubuh berasal dari proses sintesis (sekitar 700mg/hari) dan sisanya berasal dari makanan sehari-hari. ${ }^{3}$

Berdasar data WHO, prevalensi kematian akibat penyakit kardiovaskuler pada tahun 2015 meningkat menjadi 20 juta orang. ${ }^{45}$ Data Rikerdas 2013, menunjukan bahwa stroke juga meningkat dari 8,3 per 1000 pada 2007 menjadi 12,1 per 1000 pada 2013. Penduduk di atas usia 15 tahun dengan kolesterol total abnormal mencapai 35,9\%, kolesterol HDL (high-density lipoprotein) rendah 22,9\%, kolesterol LDL(low-density lipoprotein) tidak optimal dengan kategori gabungan near optimal-bonderline $60,3 \%$ dan kategori tinggi-sangat tinggi 15,9\%, trigliserida abnormal dengan kategori bonderline tinggi 13,0\% dan kategori tinggi-sangat tinggi 11,9\%. Proporsi nasional penduduk dengan konsumsi makanan berlemak, berkolesterol dan makanan gorengan lebih dari 1 kaliper hari $40,7 \%$, dan provinsi Jawa Tengah menjadi provinsi tertinggi di atas rerata nasional mencapai 60,3\%.$^{5 / 6}$ Perkiraan pada tahun 2030 kematian akibat penyakit kardiovaskuler terutama seperti penyakit jantung koroner dan stroke akan meningkat mencapai 23,3 juta jiwa. ${ }^{7 / 8}$

Radikal bebas dalam tubuh dapat berasal dari dalam (endogen) atau dari luar tubuh (eksogen). Secara endogen, radikal bebas yang berasal dari dalam 
Pengaruh Pemberian Jus Buah Naga Merah (Hylocereus Polyrhezeus) Dan Aktifitas Fisik

Terhadap Kadar Kolesterol Total dan Kadar MDA (Malondialdehide)

Oleh : Syarifah Zahra. ${ }^{1)}$ Suroto. ${ }^{2)}$ Ali Rosidi ${ }^{3)}$

tubuh akibat proses respirasi sel, proses metabolisme atau proses imflamasi. Sedangkan secara eksogen disebabkan oleh kondisi stress, sakit, radikal sinar matahari atau olah raga yang berlebihan. ${ }^{9 / 10}$

Kesibukan kerja membuat seseorang tidak punya waktu untuk melakukan aktifitas fisik seperti olahraga. Ketidak seimbangan asupan energi dari konsumsi zat gizi dengan pengeluaran energi berperan terhadap timbunan lemak dalam jaringan tubuh. ${ }^{11}$ Aktifitas fisik yang rendah atau tidak berolahraga secara rutin dan teratur akan menyebabkan meningkatnya timbunan lemak. ${ }^{12}$

Penelitian menunjukkan efek positif dari aktivitas fisik khususnya tingkat latihan olahraga terhadap faktor risiko penyakit kardio vaskuler pada orang dewasa, tetapi pada anak data masih terbatas dan samar. Hasil penelitian mendapatkan bahwa intervensi olahraga dengan sepeda statis selama 30 menit, 3 kali seminggu selama 12 minggu, terbukti secara signifikan memperbaiki kadar LDL, HDL, kolesterol total dan rasio LDL/HDL. ${ }^{13}$ Intervensi aktifitas fisik dengan olahraga teratur sangat berkontribusi dalam mengurangi timbunan lemak dalam tubuh. ${ }^{11}$

Pengendalian kadar kolesterol dalam tubuh sangat diperlukan dengan penatalaksanaan hiperkolesterolemik meliputi pengaturan diet dan pemberian obat. ${ }^{14}$ Penggunaan bahan alami seperti tanaman herbal telah banyak diteliti dan mempunyai efek samping yang kecil dibanding dengan obat kimia. ${ }^{15}$ Senyawa yang diperoleh dari sumber alami terbukti mampu melindungi tubuh dari berbagai kondisi patologi yang berbeda. ${ }^{16}$ Sebuah studi menunjukkan bahwa komponen gizi pada tanaman seperti daun dan buah dapat menurunkan kadar kolesterol, terutama daun atau buah yang banyak mengandung konsentrasi serat tinggi, antioksidan seperti flavonoid, karotenoid, vitamin dan mineral sebagai upaya pencegahan dan penanggulangan stres oksidatif..$^{11 / 17}$

Antioksidan adalah molekul yang dapat memperlambat atau mencegah terjadinya proses oksidasi lemak. Reaksi oksidasi dapat menghasilkan radikal bebas dan memicu reaksi berantai yang dapat merusak atau mematikan sebagian sel-sel tubuh. ${ }^{18}$ Oleh karena itu antioksidan sekarang ini banyak digunakan untuk 
Pengaruh Pemberian Jus Buah Naga Merah (Hylocereus Polyrhezeus) Dan Aktifitas Fisik

Terhadap Kadar Kolesterol Total dan Kadar MDA (Malondialdehide)

Oleh : Syarifah Zahra. ${ }^{1)}$ Suroto. ${ }^{2)}$ Ali Rosidi ${ }^{3)}$

mencegah dan menanggulangi stres oksidatif salah satunya adalah buah naga merah.

Buah naga merah (Hylocereus polyrhizus) merupakan salah satu tanaman yang dijadikan sebagai sumber antioksidan. Menurut penelitian, buah naga dapat menurunkan kadar kolesterol, penyeimbang kadar gula darah, mencegah kanker usus, menguatkan fungsi ginjal dan tulang, menguatkan daya kerja otak, meningkatkan ketajaman mata serta bahan kosmetik. ${ }^{19}$ Buah naga mengandung senyawa kimia vitamin C, vitamin E, vitamin A, flavonoid dan senyawa polifenol yang dapat berfungsi sebagai antioksidan dalam menangkap radikal bebas. ${ }^{20}$ Kandungan serat dalam buah naga dapat mengikat garam empedu (produk akhir kolesterol) di dalam saluran pencernaan kemudian dikeluarkan bersamaan dengan feces sehingga dapat menurunkan kadar kolesterol dalam darah. ${ }^{21}$ Kandungan protein, karbohidrat, kalsium, fosflor, magnesium dan air berfungsi sebagai beta karoten yang bermamfaat untuk kesehatan mata. ${ }^{20}$

Penelitian pemberian ekstrak buah naga merah dengan dosis $500 \mathrm{mg} / \mathrm{kg}$ berat badan (BB) secara signifikan mampu menurunkan penanda oksidatif stress. ${ }^{22}$ Pemberian ekstrak buah naga merah pada tikus hiperkolesterolemik dengan dosis $13 \mathrm{mg} / \mathrm{kgBB}$ secara signifikans mampu menurunkan kadar kolesterol total tikus. ${ }^{23}$ MDA menjadi parameter untuk mengukur ROS secara tidak langsung. Malondialdehid plasma, urin dan jaringan dapat diukur dengan cara konvensional yaitu tes TBARS. Namun spesifitas metode TBARS kurang baik. $^{24 / 25}$

Mengonsumsi makanan yang sehat dan melakukan aktifitas fisik secara teratur mampu memiliki pengaruh yang menguntungkan dalam menurunkan kadar kolesterol. Hasil penelitian menunjukkan bahwa pemberian kombinasi tepung buah naga merah dan olahraga memberikan pengaruh lebih besar dalam menghambat stress oksidatif. Kelompok perlakuan pada tikus obesitas yang diberi pakan tinggi lemak, tepung buah naga merah dan olahraga sebelum dan sesudah intervensi terdapat perbedaan signifikan penanda MDA menurun dari rerata 0,38 $\mathrm{mmol} / \mathrm{ml}$ menjadi $0,27 \mathrm{mmol} / \mathrm{ml}$. Hasil lain pemberian tepung buah naga merah 
Pengaruh Pemberian Jus Buah Naga Merah (Hylocereus Polyrhezeus) Dan Aktifitas Fisik

Terhadap Kadar Kolesterol Total dan Kadar MDA (Malondialdehide)

Oleh : Syarifah Zahra. ${ }^{1}$ Suroto. ${ }^{2}$ Ali Rosidi ${ }^{3)}$

dan olahraga juga mampu meningkatkan kapasitas aerobik tikus dari rerata 7 kali menjadi 5,67 kali. ${ }^{11}$

Banyaknya manfaat dan kandungan nutrisi buah naga merah yang diharapkan mampu untuk mencegah hiperkolestrolemik, maka penulis tertarik untuk menggunakan buah naga merah sebagai salah satu bahan untuk penelitian. Buah naga merah yang di jus diberikan bersamaan dengan pakan tinggi lemak dan tinggi kolesterol, dan aktivitas fisik terhadap kadar kolesterol total dan kadar MDA darah pada tikus Wistar Hiperkolesterolemik.

\section{B. METODE}

Penelitian ini merupakan jenis penelitian Faktorial Eksperimental (Factorial Experiment Design) dengan menggunakan rancangan penelitian dua faktorial yaitu pemberian jus buah naga merah dan olahraga renang, dengan randomized pre test -post test only control group design, menggunakan kelompok kontrol dan kelompok perlakuan, sebagai variable sederhana dengan randomisasi. Kemudian nilai-nilai setelah pre test dan post test dibandingkan untuk menentukan keefektifan perlakuan.

Sampel dalam penelitian ini adalah tikus putih jantan Rattus novergicus yang didapat dan diteliti di Laboratorium Penelitian dan Pengujian Terpadu (LPPT) Unit IV Universitas Gadjah Mada Yogyakarta. Pemeriksaan kolesterol total dan MDA di laboratorium Penelitian dan Pengujian Terpadu (LPPT) Unit I Universitas Gadjah Mada.1. Populasi Hewan yang diteliti adalah tikus putih jantan (Rattus novergicus) galur Wistar dengan berat badan 180-200 gram, yang berumur sekitar 8-10 minggu yang diperoleh dari Laboratorium Penelitian dan Pengujian Terpadu Unit IV Universitas Gadjah Mada Yogyakarta

Dalam penelitian ini tikus dibagi 5 kelompok yaitu kelompok I untuk kontrol dan kelompok 2,3,4 dan 5 untuk perlakuan sehingga jumlah tikus yang digunakan sebanyak 30 ekor tikus yang memenuhi kriteria inklusi yaitu tikus putih galur Rattus novergicus, jenis kelamin jantan, umur 8-10 minggu. berat badan 180-200 gram, mau makan dan aktif bergerak (dalam keadaan sehat). Untuk kriteria eksklusi yaitu tikus mengalami penurunan berat badan, ada 
Pengaruh Pemberian Jus Buah Naga Merah (Hylocereus Polyrhezeus) Dan Aktifitas Fisik

Terhadap Kadar Kolesterol Total dan Kadar MDA (Malondialdehide)

Oleh : Syarifah Zahra. ${ }^{1}$ Suroto. ${ }^{2}$ Ali Rosidi ${ }^{3)}$

kelainan anatomis, ada bermasalah dengan sistem pencernaan dan kriteria drop out yaitu tikus mengalami sakit dan tikus mati

Variabel Penelitian nya adalah independent variable (variabel bebas) yaitu pemberian jus buah naga merah dan aktifitas fisik dan dependent variable (variabel terikat) yaitu kadar kolesterol total dan kadar MDA darah.

Teknik analisis data meliputi: (1)Tahapan pengolahan data di mulai dengan analisis deskriptif untuk variabel kadar kolesterol total dan kadar MDA darah untuk semua kelompok pre test dan post test. (2) Analisis pengujian normalitas kolesterol total dan MDA menggunakan uji Shapiro-Wilk karena jumlah sampel kecil yaitu < 50, untuk melihat data berdistribusi normal $(\mathrm{p}>0,5)$ menggunakan nilai mean dan standart deviasi, dan data yang tidak terdistribusi normal dengan median. (3) Untuk melihat perbedaan variabel antar kelompok yang mempunyai data berdistribusi normal dan homogen di gunakan uji One Way Anova dan dilanjutkan dengan uji Post Hoc LSD (Least Significant Differences) untuk melihat perbedaan setiap kelompok. Jika terdapat perbedaan variabel yang bermakna antar kelompok dilakukan uji Mann-Whitney. Nilai signifikan dalam penelitian ini jika $\mathrm{p}<0,05$.

Hasil dan pembahasan

Setelah dilakukan masa adaptasi tikus selama 3 hari kemudian dilakukan menimbangan berat badan tikus sebagai penetapan berat badan awal. Setelah intervensi selama 28 hari dilakukan penimbangan kembali untuk penetapan berat badan akhir, bertujuan untuk memantau perubahan berat badan tikus yang berhubungan dengan pemberian pakan tinggi lemak, jus buah naga merah dan aktifitas fisik. Rerata berat badan tikus Pre-test dan Post-test penelitian berdasarkan kelompok perlakuan penelitian pada Tabel 1 . 
Pengaruh Pemberian Jus Buah Naga Merah (Hylocereus Polyrhezeus) Dan Aktifitas Fisik

Terhadap Kadar Kolesterol Total dan Kadar MDA (Malondialdehide)

Oleh : Syarifah Zahra. ${ }^{1}$ Suroto. ${ }^{2}$ Ali Rosidi ${ }^{3)}$

Tabel 1. Hasil Rerata Berat Badan Tikus Pre dan Post Perlakuan

\begin{tabular}{|c|c|c|c|c|c|}
\hline \multirow[b]{2}{*}{ Kelompok } & \multicolumn{2}{|c|}{ Berat Badan (gram) } & \multirow[b]{2}{*}{$\begin{array}{c}\Delta+ \\
\text { (gram) }\end{array}$} & \multirow[b]{2}{*}{$\Delta(\%)$} & \multirow[b]{2}{*}{$\begin{array}{c}\text { Probabilitas } \\
\text { (p) }\end{array}$} \\
\hline & $\begin{array}{c}\text { Pre-test } \\
(\text { Rerata } \pm \text { SD })\end{array}$ & $\begin{array}{c}\text { Post-test } \\
(\text { Rerata } \pm \text { SD })\end{array}$ & & & \\
\hline $\mathrm{X} 1$ & $170,783 \pm 42,271$ & $224,117 \pm 41,587$ & 53,333 & 31,229 & $0,000^{*}$ \\
\hline $\mathrm{X} 2$ & $194,450 \pm 17,851$ & $288,283 \pm 17,064$ & 93,833 & 48,256 & $0,000 *$ \\
\hline $\mathbf{X 3}$ & $183,683 \pm 21,419$ & $\begin{array}{ll}277,183 & \pm \\
22,408 & \end{array}$ & 93,500 & 50,903 & $0,000 *$ \\
\hline X4 & $191,760 \pm 17,814$ & $254,560 \pm 20,135$ & 62,800 & 32,749 & $0,000 *$ \\
\hline X5 & $175,917 \pm 17,767$ & $229,417 \pm 18,454$ & 53,500 & 30,412 & $0,000 *$ \\
\hline
\end{tabular}

Keterangan :

*) Uji-t Paired Samples Test signifikan $(\mathrm{p}<0,05)$

X1 : Kelompok Pakan Standar (PS)

X2 : Kelompok Pakan Standar+PakanTinggi Lemak (PTL)

X3 : Kelompok Pakan Standar+Pakan Tinggi Lemak+jus Buah Naga Merah (PTLBNM)

X4 : Kelompok Pakan Standar+Pakan Tinggi Lemak+Aktifitas Fisik (PTL+OR)

X5 :Kelompok Pakan standar+Pakan Tinggi Lemak+Aktifitas Fisik+jus Buah Naga Merah (PTLBNM+OR)

Terlihat pada Tabel 1, bahwa semua kelompok yang diberi Pakan Tinggi

Lemak (X2-X5) rerata pertambahan berat badannya lebih tinggi daripada kelompok kontrol (X1) yang diberi pakan standar. Hasil diet tinggi lemak menunjukkan terjadinya peningkatan berat badan meskipun terjadi penurunan asupan makanan yang signifikan. Tampaknya energi dari diet lemak memberikan penyimpanan kalori lebih tinggi yang melebihi energi yang dikeluarkan. Hasil uji homogenitas dan normalitas data rerata berat badan tikus post penelitian menunjukkan bahwa data berat badan tikus homogen $(p>0,05)$, namun tidak terdistribusi normal $(\mathrm{p}<0,05)$. Untuk mengetahui ada pengaruh perlakuan atau tidak, dilanjutkan dengan Uji non parametrik Uji Kruskal Hasil uji Kruskal Wallis menunjukkan terdapat pengaruh perlakuan terhadap berat badan tikus post penelitian $(\mathrm{p}<0,05)$. Jika ditinjau dari data selisih berat badan antara sebelum dan sesudah intervensi terdapat kecenderungan penurunan berat badan pada kelompok PTL+OR, PTLBNM, dan PTLBNM+OR, sedangkan pada kelompok PS dan PTL terjadi peningkatan.

Hasil uji Mann Whitney data selisih berat badan tikus, didapatkan bahwa terdapat perbedaan bermakna antara kelompok X1 dengan X2 (nilai signifikansi 0,002), X1 dengan X3 (nilai signifikansi 0,002), X1 dengan X4 (nilai signifikansi 0,004), X2 dengan X4 (nilai signifikansi 0,004), X2 dengan X5 (nilai signifikansi 0,002), X3 dengan X4 (nilai signifikansi 0,004), X3 dengan X5 (nilai signifikansi 0,002), dan X4 dengan X5 (nilai signifikansi 0,004). Sedangkan antara kelompok X1 dengan X5 (nilai signifikansi 0,937), X2 dan X3 (nilai signifikansi 0,937) tidak terdapat perbedaan yang bermakna. 
Pengaruh Pemberian Jus Buah Naga Merah (Hylocereus Polyrhezeus) Dan Aktifitas Fisik

Terhadap Kadar Kolesterol Total dan Kadar MDA (Malondialdehide)

Oleh : Syarifah Zahra. ${ }^{1}$ Suroto. ${ }^{2}$ Ali Rosidi ${ }^{3)}$

\section{Kadar Kolesterol Total Darah Tikus}

Pre test pemeriksaan kadar kolesterol total tikus dilakukan setelah pemberian pakan tinggi lemak selama 14 hari, dan post test pemeriksaan kadar kolesterol total tikus dilakukan setelah perlakuan selama 14 hari dengan pemberian jus buah naga dan aktivitas fisik.

Kolesterol total adalah salah satu variabel lipid yang berpengaruh besar terhadap kadar lipid plasma.Rerata kadar Kolesterol total darah tikus Pre-test dan Post-test penelitian berdasarkan kelompok perlakuan tersaji pada Tabel 2

Tabel 2. Rerata Kadar Kolesterol Total Darah Tikus Pre Dan Post Penelitian Berdasarkan Kelompok

\begin{tabular}{|c|c|c|c|c|c|}
\hline \multirow[b]{2}{*}{ Kelompok } & \multicolumn{2}{|c|}{ Kadar Kolesterol (mg/dl) } & \multirow[b]{2}{*}{$\begin{array}{c}\text { Selisih (+) } \\
(\mathrm{mg} / \mathrm{dl})\end{array}$} & \multirow[b]{2}{*}{$\begin{array}{c}\text { Selisih } \\
(\%)\end{array}$} & \multirow[b]{2}{*}{$\begin{array}{l}\text { Probabilit } \\
\text { as (p) }\end{array}$} \\
\hline & $\begin{array}{c}\text { Pre-test } \\
(\text { Rerata } \pm \text { SD })\end{array}$ & $\begin{array}{c}\text { Post-test } \\
(\text { Rerata } \pm \text { SD })\end{array}$ & & & \\
\hline $\mathbf{X 1}$ & $49,083 \pm 12,875$ & $54,817 \pm 3,621$ & & & \\
\hline $\mathbf{X} 2$ & $52,783 \pm 8$, & $63,000 \pm 7,892$ & 10 & 19 & $9 *$ \\
\hline $\mathbf{X 3}$ & $52,150 \pm$ & 57 & 3 & 10,897 & $0,041 *$ \\
\hline X4 & $56,350 \pm 5,261$ & $64,080 \pm 13,317$ & 7,730 & 13,718 & 0,278 \\
\hline X5 & $54,317 \pm 10,854$ & $57,217 \pm 8,614$ & 2,900 & 5,339 & 0,495 \\
\hline
\end{tabular}

Keterangan :

*) Uji-t Paired Samples Test signifikan $(\mathrm{p}<0,05)$

Uji-t Paired Samples Test tidak signifikan $(\mathrm{p}>0,05)$

$\mathrm{X} 1$ : Kelompok Pakan Standar (PS)

X2: Kelompok Pakan Standar+PakanTinggi Lemak (PTL)

X3 : Kelompok Pakan Standar+Pakan Tinggi Lemak+jus Buah Naga Merah (PTLBNM)

X4 : Kelompok Pakan Standar+Pakan Tinggi Lemak+Aktifitas Fisik (PTL+OR)

X5 : Kelompok Pakan standar+Pakan Tinggi Lemak+Aktifitas Fisik+jus Buah Naga Merah (PTLBNM+OR)

Pada Tabel 2 terlihat bahwa kelompok yang diberi PTL (kelompok X2$\mathrm{X} 5)$ rerata kadar kolesterol total awal lebih tinggi apabila dibandingkan dengan kelompok yang diberi pakan standar (X1). Pemberian makan tikus dengan diet kaya kolesterol akan mengakibatkan peningkatan total kolesterol. ${ }^{31}$

Rerata kadar kolesterol total pre-test paling tinggi adalah kelompok X4 $(56,350 \mathrm{mg} / \mathrm{dl})$ dan terendah kelompok X1 (49,083 mg/dl)apabila dibandingkan dengan kelompok pre-test lainnya. Demikian juga rerata kadar kolesterol total post-test tertinggi adalah kelompok X4 $(64,080 \mathrm{mg} / \mathrm{dl})$ dan terendah adalah kelompok X1 (54,817 mg/dl) apabila dibandingkan dengan kelompok post-test lainnya.

Apabila membandingkan antara pre-test dengan post-test, terjadi kenaikan kadar kolesterol total pada semua kelompok penelitian; kenaikan kadar kolesterol total tertinggi adalah pada kelompok X2 sebesar 19,357\%. Perbedaan secara bermakna $(\mathrm{p}<0,05)$ pada kadar kolesterol total pre-test dengan post-test terjadi pada kelompok perlakuan X2 dan X3. 
Pemberian PTL pada kelompok X2 secara bermakna meningkatkan kadar kolesterol total pada akhir penelitian. Hal ini sejalan dengan hasil penelitian bahwa pemberian diet tinggi lemak atau tinggi kolesterol akan menaikkan kadar kolesterol total darah tikus. ${ }^{27,31}$

Pada kelompok dengan pemberian aktivitas fisik (X4) maupun kelompok dengan pemberian aktivitas fisik+jus buah naga merah (X5) tidak terjadi perubahan kadar kolesterol total plasma darah tikus (non signifikan). Hal ini berbeda dengan hasil penelitian sebelumnya bahwa kelompok tikus perlakuan yang diberikan intervensi olahraga secara signifikan dapat menurunkan kolesterol total, sedangkan kelompok yang diberikan kombinasi buah naga merah dan olahraga memiliki pengaruh lebih besar terhadap penurunan kolesterol total dibandingkan dengan yang diberikan pakan buah naga merah maupun olahraga saja. ${ }^{57}$

Hasil uji homogenitas dan normalitas data kadar kolesterol total plasma darah tikus menunjukkan homogen $(p>0,05)$ dan berdistribusi normal, bahwa varian dari kelompok populasi data kadar kolesterol total adalah sama (homogen) dan tersebar normal, sehingga data kadar kolesterol total dapat dilakukan uji statistik parametrik Uji ANOVA. Uji ANOVA dilakukan untuk melihat indikasi tentang ada tidaknya perbedaan antar rerata data kadar kolesterol total dari keseluruhan kelompok perlakuan. Hasil uji one way ANOVA data selisih kadar kolesterol total tercantum pada Tabel 3 berikut ini :

Tabel 3. Hasil Uji Anova Data Selisih Kadar Kolesterol Total Berdasar Kelompok Perlakuan

\begin{tabular}{|c|c|c|c|c|c|}
\hline \multirow{3}{*}{ Variabel } & \multicolumn{5}{|c|}{ Kelompok Perlakuan } \\
\hline & X1 & $\mathbf{X} 2$ & $\mathbf{X 3}$ & $\mathbf{X 4}$ & $\mathbf{X 5}$ \\
\hline & Rerata \pm SD & Rerata \pm SD & Rerata \pm SD & Rerata \pm SD & Rerata \pm SD \\
\hline $\begin{array}{c}\text { Kadar } \\
\text { Kolesterol } \\
(\mathrm{mg} / \mathrm{dl})\end{array}$ & $\begin{array}{c}5,733 \pm \\
7,4430\end{array}$ & $\begin{array}{c}10,217 \pm \\
9,6680\end{array}$ & $\begin{array}{c}5,683 \pm \\
5,0905\end{array}$ & $\begin{array}{l}7,940 \pm \\
14,1398\end{array}$ & $\begin{array}{c}2,900 \pm \\
9,6522\end{array}$ \\
\hline $\begin{array}{l}\text { Probabilitas } \\
\text { (p)* }\end{array}$ & 0,736 & 0,736 & 0,736 & 0,736 & 0,736 \\
\hline
\end{tabular}

*) Nilai Signifikansi > 0,05, tidak terdapat perbedaan pengaruh perlakuan

Pada Tabel 3 hasil uji ANOVA data selisih kadar kolesterol total tidak berbeda $(p>0,05)$, yaitu tidak terdapat perbedaan pengaruh antar kelompok perlakuan . Pemberian jus buah naga merah belum mampu menurunkan kadar kolesterol total darah tikus hiperkolesterolemik.

Pada penelitian ini pemberian jus buah naga merah belum mampu menurunkan kadar kolesterol darah tikus; hal ini diduga bahwa kandungan serat dan sifat antioksidan dalam buah naga merah yang memiliki pengaruh signifikan dalam mengubah metabolisme lipidbelum dapat bekerja secara optimal selama masa penelitian, sehingga belum mampu menekan kenaikan kadar kolesterol total. 
Pengaruh Pemberian Jus Buah Naga Merah (Hylocereus Polyrhezeus) Dan Aktifitas Fisik

Terhadap Kadar Kolesterol Total dan Kadar MDA (Malondialdehide)

Oleh : Syarifah Zahra. ${ }^{1}$ Suroto. ${ }^{2}$ Ali Rosidi ${ }^{3)}$

Pemberian aktifitas fisik berupa kegiatan renang selama 5 menit dengan frekuensi $3 \mathrm{kali} /$ minggu pada penelitian ini belum mampu menurunkan kadar kolesterol total darah tikus hiperkolesterolemik; diduga karena aktivitas fisik yang dilakukan belum mampu memfasilitasi mobilisasi dan oksidasi lemak terutama pada jaringan adiposa viseral yang akan menyebabkan penurunan kadar lemak tubuh karena meningkatnya metabolisme basal pada sel-sel tubuh $^{61}$.

\section{Kadar MDA (malondialdehyde) Darah Tikus}

Hasil pengujian kadar MDA darah tikus pre-test dan post-test penelitian berdasarkan kelompok perlakuan tercantum pada Tabel 4 .

Tabel 4. Rerata Kadar MDA Darah Tikus Pre Dan Post Penelitian Berdasarkan Kelompok Perlakuan

\begin{tabular}{cccccc}
\hline \multirow{2}{*}{ Kelompok } & \multicolumn{2}{c}{ Kadar MDA (pmol/mg) } & Selisih (-) & $\begin{array}{c}\text { Selisih } \\
(\mathbf{P})\end{array}$ & $\begin{array}{c}\text { Probabilitas } \\
(\mathbf{p})\end{array}$ \\
\cline { 2 - 5 }$(\mathbf{\text { Perata }} \pm \mathbf{S D})$ & $\begin{array}{c}\text { Post-test } \\
(\text { Rerata } \pm \text { SD) }\end{array}$ & & & \\
\hline X1 & $3,008 \pm 0,290$ & $2,530 \pm 0,388$ & 0,478 & 15,891 & 0,105 \\
X2 & $2,773 \pm 0,242$ & $1,690 \pm 0,483$ & 1,083 & 39,055 & $0,001^{*}$ \\
X3 & $2,915 \pm 0,333$ & $1,927 \pm 0,282$ & 0,988 & 33,894 & $0,002^{*}$ \\
X4 & $2,845 \pm 0,262$ & $1,314 \pm 0,716$ & 1,531 & 53,814 & $0,014^{*}$ \\
X5 & $2,648 \pm 0,298$ & $2,192 \pm 0,467$ & 0,456 & 17,221 & 0,116 \\
\hline
\end{tabular}

Keterangan :

*) Uji-t Paired Samples Test signifikan $(\mathrm{p}<0,05)$

X1 : Kelompok Pakan Standar (PS)

X2 : Kelompok Pakan Standar+PakanTinggi Lemak (PTL)

X3 : Kelompok Pakan Standar+Pakan Tinggi Lemak+jus Buah Naga Merah (PTLBNM)

X4: Kelompok Pakan Standar+Pakan Tinggi Lemak+Aktifitas Fisik (PTL+OR)

X5 : Kelompok Pakan standar+Pakan Tinggi Lemak+Aktifitas Fisik+jus Buah Naga Merah (PTLBNM+OR)

Pada Tabel 4 terlihat bahwa terjadi penurunan kadar MDA pada semua kelompok penelitian; penurunan kadar MDA terbesar adalah pada kelompok X4 sebesar 53,814\%. Terjadi penurunan kadar MDA secara bermakna pada kelompok perlakuan X2, X3 dan X4 pada akhir penelitian (post-test). Hal ini sejalan dengan hasil penelitian bahwa terdapat kecenderungan penurunan kadar MDA pada semua kelompok perlakuan (PS, PTL, PTLBNM, PTL+OR dan PTLBNM+OR) namun tidak terdapat hubungan yang signifikan antar perlakuan. ${ }^{15}$

Rerata kadar MDA pre-test paling tinggi adalah kelompok X1 (3,008 $\mathrm{pmol} / \mathrm{dl})$ dan terendah kelompok X5 (2,648 pmol/dl) apabila dibandingkan dengan kelompok pre-test lainnya. Demikian juga rerata kadar MDA post-test tertinggi adalah kelompok X1 (2,530 pmol/dl) dan terendah adalah kelompok X4 (1,314 $\mathrm{pmol} / \mathrm{dl}$ ) apabila dibandingkan dengan kelompok post-test lainnya.

Hasil uji homogenitas dan normalitas data selisih kadar MDA darah tikus penelitian adalah homogen $(\mathrm{p}>0,05)$ dan berdistribusi normal; bahwa varian data selisih kadar MDA berasal dari kelompok populasi yang sama (homogen) dan tersebar normal, sehingga data selisih kadar MDA dapat dilakukan uji statistik 
Pengaruh Pemberian Jus Buah Naga Merah (Hylocereus Polyrhezeus) Dan Aktifitas Fisik Terhadap Kadar Kolesterol Total dan Kadar MDA (Malondialdehide)

Oleh : Syarifah Zahra. ${ }^{1}$ Suroto. ${ }^{2}$ Ali Rosidi ${ }^{3)}$

parametrik One Way Anova. Uji One Way Anova dilakukan untuk melihat indikasi tentang ada tidaknya perbedaan antar rata-rata dari keseluruhan kelompok perlakuan. Hasil uji one way ANOVA data selisih kadar MDA tercantum pada Tabel 5

Tabel 5. Hasil Uji Anova Data Selisih Kadar MDA Berdasar Kelompok Perlakuan

\begin{tabular}{cccccc}
\hline \multirow{2}{*}{ Variabel } & \multicolumn{5}{c}{ Kelompok Perlakuan } \\
\cline { 2 - 6 } & Rerata \pm SD & Rerata \pm SD & Rerata \pm SD & Rerata \pm SD & Rerata \pm SD \\
\hline & $-0,477 \pm$ & $-1,084 \pm$ & $-0,988 \pm$ & $-1,580 \pm$ & $-0,456 \pm$ \\
Kadar MDA & 0,518 & 0,419 & 0,850 & 0,588 \\
\hline pmol/mg) & 0,591 & 0,418 & $0,020^{*}$ & $0,020^{*}$ & $0,020^{*}$ \\
$\begin{array}{c}\text { Probabilitas } \\
(\mathrm{p})\end{array}$ & $0,020^{*}$ & $0,020^{*}$ & & & \\
\hline
\end{tabular}

*) Nilai Signifikansi $<0,05$, terdapat pengaruh perlakuan

Pada Tabel 5 hasil uji One Way Anova data selisih kadar MDA adalah signifikan $(\mathrm{p}<0,05)$ sehingga dapat dilanjutkan dengan uji post hock LSD, untuk mengetahui perbedaan pengaruh antar kelompok perlakuan. Hasil uji Post Hock LSD (Least Significant Differences)/Beda Nyata Terkecil data selisih kadar MDA tercantum pada Tabel 6.

Tabel 6. Hasil Uji Post Hock LSD Data Selisih Kadar MDA Berdasarkan Kelompok Perlakuan

\begin{tabular}{cccccc}
\hline Kelompok & \multicolumn{5}{c}{ Kelompok Perlakuan } \\
\cline { 2 - 6 } Perlakuan & $\mathbf{X 1}$ & $\mathbf{X 2}$ & $\mathbf{X 3}$ & $\mathbf{X 4}$ & $\mathbf{X 5}$ \\
\cline { 2 - 6 } & - & $0,005^{*}$ & $0,038^{*}$ & $0,000^{*}$ & 0,231 \\
X1 & - & - & 0,398 & 0,205 & 0,081 \\
X2 & - & - & - & $0,044^{*}$ & 0,344 \\
X3 & - & - & - & - & $0,006^{*}$ \\
X5 & - & - & - & - & - \\
\hline
\end{tabular}

*) Terdapat perbedaan antar perlakuan $(\mathrm{p}<0,05)$

Pada Tabel 6 hasil uji post hock menunjukkan bahwa terdapat perbedaan bermakna antara kelompok X1 dengan X2 (nilai signifikansi 0,050), X1 dengan X3 (nilai signifikansi 0,038), X1 dengan X4 (nilai signifikansi 0,000), X3 dengan X4 (nilai signifikansi 0,044) dan X4 dengan X5 (nilai signifikansi 0,006). Sedangkan antara kelompok X1 dengan X5 (nilai signifikansi 0,231), X2 dengan X3 (nilai signifikansi 0,398), X2 dengan X4 (nilai signifikansi 0,205), X2 dengan X5 (nilai signifikansi 0,081) dan X3 dengan X5 (nilai signifikansi 0,344) tidak terdapat perbedaan yang bermakna.

Kelompok perlakuan X4 (PTL+OR)memiliki kadar MDA yang paling rendah, dimana mendapatkan pakan tinggi lemak dan terapi aktifitas fisik; aktifitas fisik 
Pengaruh Pemberian Jus Buah Naga Merah (Hylocereus Polyrhezeus) Dan Aktifitas Fisik

Terhadap Kadar Kolesterol Total dan Kadar MDA (Malondialdehide)

Oleh : Syarifah Zahra. ${ }^{1}$ Suroto. ${ }^{2}$ Ali Rosidi ${ }^{3)}$

memiliki efek positif pada penurunan nafsu makan akibat penurunan hormon ghrelin. Ghrelin merupakan hormon yang dapat meningkatkan konsumsi makanan melalui peningkatan nafsu makan. ${ }^{62}$ Penurunan nafsu makan akan berakibat pada penurunan konsumsi pakan tinggi lemak, sehingga kadar kolesterol yang berperan dalam produksi radikal bebas dalam darah akan menurun pula. Penurunan radikal bebas akan menurunkan tingkat stres oksidatif, sehingga akan menurun pula tingkat penanda stres oksidatif (MDA) dalam darah.

Kadar MDA kelompok X5 (PTLBNM+OR) tidak berbeda secara bermakna dengan sebagian besar kelompok penelitian (K1-K3). Hasil penelitian menunjukkan bahwa potensi antioksidan exogen dari bubuk buah naga merah seperti : flavonoid, antosianin, asam fenolik, karamel dapat menghambat peningkatan kadar MDA dalam plasma darah tikus, terutama untuk kelompok yang diberi PTL, PTL ditambah latihan berenang, bubuk buah naga merah ditambah PTL dan bubuk buah naga merah ditambah latihan berenang. ${ }^{15}$

\section{Korelasi Kadar Kolesterol Total dan MDA}

Stres oksidatif dapat dipicu oleh makanan tinggi lemak dan kurang atau berlebihannya aktifitas fisik, stres oksidatif merupakan kondisi berlebihnya ROS yang ditandai dengan meningkatnya kadar MDA dalam darah. Semakin tinggi kadar kolesterol maka semakin tinggi kadar MDA dalam darah.

\section{KESIMPULAN}

Pertama Pemberian jus buah naga merah tidak berpengaruh terhadap kadar kolesterol total tikus hiperkolesterolemik. Kedua Pemberian jus buah naga merah berpengaruh terhadap kadar MDA darah tikus hiperkolesterolemik. Ketiga Pemberian aktifitas fisik tidak berpengaruh terhadap kadar kolesterol total tikus hiperkolesterolemik. Keempat Pemberian aktifitas fisik berpengaruh terhadap kadar MDA darah tikus hiperkolesterolemik. Kelima Pemberian jus buah naga merah dan aktifitas fisik tidak berpengaruh terhadap kadar kolesterol total darah tikus hiperkolesterolemik. Keenam Pemberian jus buah naga merah dan aktifitas fisik berpengaruh terhadap kadar MDA darah tikus hiperkolesterolemik. 


\section{DAFTAR PUSTAKA}

1. Milias AG, Demosthenes BP, Christos P, Dimitra X, Georgia P, Christodoulos S. Prevalance of Self-Reported Hypercholesterolemia and its Relation to Dietary Habits, In Greek Adults; A National Nutrition and Health Survey. Lipid in Health and Disease. 2006; 5(5).

2. Amin KA, Abd. El-Twab TM. Oxidative markers, nitric oxide and homocysteine ateration in hypercholesterolemic rats: role of atorvastatine and cinnamon. Int J Clin Exp Med. 2009; 2(3):2 54-65.

3. Botham KM, Mayes PA. Sintesis, Transpor, dan Ekskresi Kolesterol. Dalam Murray RK, Bender DA, Botham KM, Kennely PJ, Rodwell VW, Weil PA, editor. Biokimia Harper. Jakarta: EGC; p. 158-15; 2014.

4. World Health Organization. World Health Statistic. Italy; 2013

5. Darni J, Kusmiyati-Tjahjono, Sofro MAU, Pengaruh Pemberian Ekstrak Daun Alfafa (Medicago Sativa) terhadap Profil Lipid dan Kadar Malondialdehide (MDA) Tikus Hiperkolesterolemik (Tesis), Semarang: Universitas Diponegoro; 2016.

6. Badan Penelitian dan Pengembangan Kemenkes RI. Laporan Hasil Riset Kesehatan Dasar (Riskerdas) Nasional. Jakarta; 2013.

7. World Health Organization. Global status report on noncommunicable disease (NCDs) 2012. Geneva Report; 2013.

8. Damayanty AE, Suromo LB, Kisdjamiatun. Pengaruh Pemberian Ekstrak Jamur Merang (Volvariella volvacea) Terhadap Kadar Kolesterol Total, Enzim LpPLA2 dan MDA Darah (Tesis) Semarang: Universitas Diponegoro; 2015.

9. Pham-Huy LA, He H, Pham-Huy C. Free Radical, Antioxidans in Disease and Health.Int. J, Biomed Sci. 2008; 4(2): 89-96.

10. Suwandi T. Pemberian ekstraks kelopak bunga rosela menurunkan malondialdehide pada tikus yang diberi minyak jelantah (Tesis). Denpasar: Universitas Udayana; 2012.

11. Maigoda TC. Pengaruh tepung buah naga merah (Hylocereus polyrhizus) dan olahraga renang terhadap penanda inflamasi, stres oksidatif dan kebugaran pada tikus jantan (Sprague dawley) dengan obesitas. Scientific Repository (Disertasi). Bandung: Institut Pertanian Bogor; 2016. 
Pengaruh Pemberian Jus Buah Naga Merah (Hylocereus Polyrhezeus) Dan Aktifitas Fisik

Terhadap Kadar Kolesterol Total dan Kadar MDA (Malondialdehide)

Oleh : Syarifah Zahra. ${ }^{1}$ Suroto. ${ }^{2}$ Ali Rosidi ${ }^{3)}$

12. Tolfrey K, Campbell IG, Batterham AM. Exercise training induced alterations in prepubertal children's lipid-lipoprotein profile. Med Sci Sport Exerc. 1998; 30(12): 1684-92.

13. Anam MS, Pengaruh Intervensi Diet dan Olahraga terhadap Indeks Massa Tubuh, Kesegaran Jasmani, hsCRP dan Profil Lipid pada Anak Obesitas (Tesis), Semarang: Universitas Diponegoro; 2010.

14. World Health Organization. Prevention and treatment both work says who study on heart disease. Global status report on noncommunicable diseases 2010. World Health Organization 2011 Reprinted 2011; Italy; 2011.

15. Subashini R and Rajadurai M. Evaluation of cardioprotective efficacy of Nelumbo nucifera leaf extract on isoproterenol-induced myocardialinfarction in Wistar rats. International Journal of Pharmacology and Biological Sciences. 2011; 2(4): 34-45.

16. Layli AN, Djamiatun K, Kartasurya MI. Pemanfaatan ektraks daun kersen (Muntingia calabura L) terhadap kadar kolesterol darah, kadar soluble Icam-1 dan pembentukan sel busa pada tikus wistar (Tesis). Semarang:Universitas Diponegoro; 2015.

17. Oenzil F. Gizi meningkatkan kualitas manula. Jakarta: EGC; 2012; p. 79-80.

18. Lianawati MMV. Pemberian ekstrak buah naga merah (Hylocereus polyrhizus) menurunkan kadar F2 Isoprostan pada tikus putih jantan (Albino rat) yang diberi aktivitas berlebih (Tesis). Denpasar: Universitas Udayana; 2011

19. Wahyuni R. Pemanfaatan kulit buah naga super merah (Hylocereus costaricensis) sebagai sumber antioksidan dan pewarna alami pada pembuatan jelly. Teknologi Pangan. 2011; 2(1).

20. Banawati R, Mahajoeno E. Variasi morfologi, isozim dan kandungan vitamin C pada varietas buah naga (Tesis). Surakarta: Universitas Sebelas Maret; 2010 .

21. Swarup KRLA, Sattar MA, Abdullah NA, Abdulla MH. Salman IM, Rathore HA, et al. Effect of dragon fruit extract on oxidative. Res. 2010; 2(1); 31-35.

22. Sani HA, Baharoom A, Ahmad M.A, Ismail II, Effectiveness of hylocereus polyhrizus extract in decreasing serum lipids and liver MDA-TBAR level in hypercoholesterolemic Rats. Available from: https://www.researchgate.net/publication/288091560. 2009.

23. Heryani R. Pengaruh ekstrak buah naga merah terhadap profil lipid pada tikus putih hiperlipidemia. Jurnal Ipteks Terapan. 2016; 10(1); (8-17). 
Pengaruh Pemberian Jus Buah Naga Merah (Hylocereus Polyrhezeus) Dan Aktifitas Fisik

Terhadap Kadar Kolesterol Total dan Kadar MDA (Malondialdehide)

Oleh : Syarifah Zahra. ${ }^{1}$ Suroto. ${ }^{2}$ Ali Rosidi ${ }^{3)}$

24. Halliwell B, Whiteman M. Measuring reactive species and oxidative damage in vivo and in cell culture: how should you do it and what do the result mean?. British Journal of Pharmacology. 2004; 142: 231-255.

25. Liana L. Pemberian minuman ekstrak teh hijau suhu hangat dan suhu dingin menurunkan kadar MDA serum pada tikus dengan diet tinggi karbohidrat dan tinggi lemak (Tesis). Denpasar: Universitas Udayana; 2011.

Biodata penulis :

$\begin{array}{ll}\text { Nama } & : \text { Syarifah Zahra. }{ }^{1)} \text {,Suroto, M.Pd. }{ }^{2)}, \text { Ali Rosidi. } \\ & \text { szahrapjkr@ gmail.com } \\ \text { Kantor } & : \text { PJKR FKIP UNWAHAS }\end{array}$

